\title{
Tick bite cases among hazelnut farm workers in Giresun
}

\section{Giresun yöresinde fındık isççileri arasında görülen kene tutma vakaları}

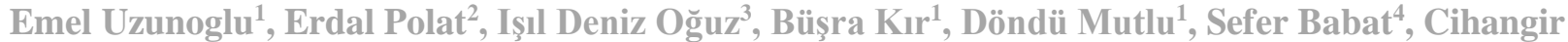
Akdemirir ${ }^{1}$

${ }^{1}$ Giresun Üniversitesi, Tip Fakültesi, Tibbi Mikrobiyoloji Anabilim Dal, Giresuı

${ }^{2}$ İstanbul Üniversitesi, Cerrahpaşa Tip Fakültesi, Tibbi Parazitoloji Bilim Dalı, İstanbul

${ }^{3}$ Giresun Prof. Dr. A. İlhan Özdemir Devlet Hastanesi, Dermatoloji Kliniği, Giresun

${ }^{+}$Şınak Üniversitesi, Şırnak Meslek Yüksek Okulu, Șirnak

Corresponding author: Emel Uzunoglu, Giresun Üniversitesi, Tip Fakültesi, Tibbi Mikrobiyoloji Anabilim Dalı, Nizamiye Mahallesi, Orhan Y1lmaz

Caddesi, 28200, Giresun

E-mail: emeluzunoglu@yahoo.com

Received/Accepted: September 07, 2016/April 04, 2017

Conflict of interest: There is not a conflict of interest.

\section{SUMMARY}

Objective: Ticks are arthropod vectors of many diseases. The prevalence of Lyme disease transmitted by Ixodes is not known in Turkey. The disease is caused by Borrelia species and can also be seen in domestic animals. The aim of this study is to identify the ticks, which are collected from the agricultural workers who admitted to hospitals during the hazelnut harvest season between August and September 2015, at species and genus level and investigate whether these ticks vector of Borrelia spp.

Method: In this study, 152 ticks collected from 134 patients were investigated. Of all samples including larvae and nymphs, 95.24\% were collected in September. All patients who admitted with complaints of tick bites were agricultural workers collecting nuts in the gardens at sea level. The ticks were identified at species and genus level with stereomicroskop, hemolymph fluid examined directly by dark-field microscope and cultured in the Borellia BarbourStoenner-Kelly (BSK-H) medium.

Results: Of all the ticks, $126(82.9 \%)$ were adults, $13(8.55 \%)$ were nymphs and $13(8.55 \%)$ were larvae. Stereoscopic examination of the ticks revealed that $125(82.2 \%)$ of the adults were Ixodes ricinus and $1(0.65 \%)$ was Rhipicephalus sanguineus. All of the 13 nymphs (8.55\%) and 13 larvae (8.55\%) were identified as Ixodes spp.. All forms of development cycle were detected in the samples and the forms were inconsistent with the expected development cycle. Borrelia spp., the agent of Lyme disease, was investigated in the 146 ticks defined as I. ricinus and Ixodes spp. Borrelia spp were detected by dark field microscope in 3 (2.05\%) of the 146 Ixodes and Borrelia spp. were identified in 5 (3.4\%) of the cultures.

Conclusions: These results demonstrate that Lyme disease can be seen in our region and the most probable vector is Ixodes ricinus.

Keywords : Ixodes ricinus, Lyme disease, Borrelia spp.

\section{ÖZET}

Amaç: Keneler pek çok hastalığa vektörlük eden artropodlardır. Ixodes cinsi kenelerin bulaştırdığı Lyme hastalığının Türkiye'deki prevalansı bilinmemektedir. Evcil hayvanlarda da görülebilen bu hastalığa Borrelia cinsi bakteriler neden olmaktadır. Bu çalışmanın amacı, 2015 Ağustos ve Eylül aylarında findık hasat mevsiminde kene tutunma şikayeti ile hastanelere başvuran hastalardan izole edilen keneleri cins ve/veya tür düzeyinde tanımlamak ve Borrelia spp. vektörü olup olmadıklarını belirlemektir.

Yöntem: Çalışmamız, 134 hastadan toplanan 152 kene üzerinde yapılmıştır. Larva ve nimfler dahil örneklerin \%095,24'ü Eylül ayında toplanmıştır. Kene tutma şikâyetiyle müracaat eden tüm hastalar deniz seviyesindeki bahçelerde findık toplayan tarım iş̧̧ilerinden oluşmaktadır. Keneler stereomikroskop ile incelenerek cins ve tür düzeyinde tanımlanmış, hemolenf sıvıları karanlık alan mikroskobu ile direkt olarak incelenmiş ve Borellia Barbour-Stoenner-Kelly (BSK-H) besiyerinde kültürü yapılmıştır.

Bulgular: Kenelerin $126(\% 82,9)$ 'sı erişkin, 13 (\%8,55)'ü nimf ve 13 (\%8,55)'ü larva olarak saptanmıştır. Erişkinlerin 125 (\%82,2)'i Ixodes ricinus, 1 (\%0,65)'i Rhipicephalus sanguineus, 13 nimf $(\% 8,55)$ ve 13 larvanın $(\% 8,55)$ tamamı ise Ixodes spp. olarak bulunmuştur. Bütün gelişim formları bir arada ve beklenen döngülerinin dişında saptanmıştır I. ricinus 
türü ve Ixodes spp. olarak tanımlanan kenelerin 146'sında Lyme hastalığı etkeni Borellia cinsi bakteriler araştırılmıștır. Ixodes cinsi 146 kenenin $3(\% 2,05)$ 'ünde karanlık alan mikroskobu ile Borrelia spp görülmüş, $5(\% 3,4)$ 'inde ise kültürde Borrelia spp. üremiştir.

Sonuç: Bu sonuç yöremizde Lyme hastalığının görülebileceğini ve bölgemizde rol alabilecek ana vektörün de Ixodes ricinus olabileceğini düşündürmektedir.

Anahtar sözcükler: Ixodes ricinus, Lyme hastalığı, Borrelia spp.,

\section{INTRODUCTION}

Ticks are obligate blood-sucking ectoparasites throughout their development stages and take the second place after the mosquitos among vector arthropods that threaten human health all over the world ${ }^{1}$. Tick species can vary depending on the geographic and climatic conditions such as humidity, precipitation, vegetation and the presence of domestic and wild animals ${ }^{2}$. Subtropical climate zone, which also includes Turkey, is a geography that provides desired conditions for ticks to pursue their biological activities ${ }^{3}$.

It is well known that ticks transmit approximately two hundred different diseases to humans and animals ${ }^{4}$. Overall in Turkey, Hyalomma and Rhipicephalus spp. are common among ticks collected from human hosts and especially Hyalomma spp. often come to the fore because of being the agent of Crimean-Congo Hemorrhagic Fever (CCHF), which may cause severe clinical consequences $^{2,}{ }^{4}$. Babesiosis, erlichiosis (HGE), tick typhus (rickettsioses), tularemia and filariasis (subcutaneous form) can be considered among the diseases that can be transmitted by Ixodes spp. ${ }^{5}$. Tick-borne diseases that affect human and animal health cause significant economic losses worldwide ${ }^{6,7}$.

The precise prevelance of Lyme disease transmitted through Ixodes spp. in Turkey is not known because it is not included in notifiable diseases and can easily be confused with other diseases. The disease is caused by Borrelia spp. and can also be seen in domestic animals ${ }^{8}$. Borrelia burgdorferi sensu stricto, Borrelia garinii and Borrelia afzelii are the three genotypes that cause Lyme disease in humans, all being subsumed under the name B. burgdorferi sensu lato ${ }^{9}$. Lyme disease caused by the spirochete Borrelia genus is the most common zoonotic disease in North America, Asia and Europe ${ }^{10}$.

The data about species and genus of the ticks isolated from patients in Black Sea Coast Region and infective agents that are transmitted through these ticks are missing. In this study, the ticks collected from the agricultural workers who admitted to emergency departments in the nutcollecting season in summer were identified at species and genus level and it was investigated whether these ticks vector Borrelia spp.

\section{MATERIAL AND METHODS}

A total of 152 ticks (126 adult +13 nymph +13 larvae) collected from 134 nut farm workers who admitted to emergency department between August and September 2015 were included in the study.

The ticks collected from the patients were placed in screw capped plastic containers $100 / 15 \mathrm{~mm}$ in size. Small holes were previously opened in these tubes for venting and green leaf pieces were placed in order to provide appropriate humidity. All the ticks collected from the same patient were placed in a seperate tube and the information about the date and the place that the ticks were collected were noted on these tubes. In this way, the ticks were transported to the laboratory and they were identified at species level by using stereomicroscope (Olympus SZX10) when they were alive ${ }^{11-13}$. Six of the ticks were excluded from the study since they were not alive during the laboratory examination. A total of 146 Ixodes genus ticks were placed in first petri filled with sterile distilled water and kept there for 3-5 minutes and then were taken to the second petri containing $70 \%$ ethyl alcohol. After 3-5 minutes in the second petri, the ticks were placed in the third petri again filled with sterile distilled water and kept there for 3-5 minutes. The ticks were then placed on a sterile slide and the tail of each tick was dissected by a sterile scalpel in order to take the hemolymph and digestive system out by pushing the body of the tick gently. The collected part was crushed in physiological serum and covered with lamellae in order to search for Borrelia spp. via dark-field microscope (Zeiss AX10) at 200X and 400X magnification. Barbour-Stoenner-Kelly (BSK-H) medium was used for the culture of the organism. The information about the regions from where our patients collected nuts were also noted down in our study.

\section{RESULTS}

Of all ticks, $126(82.9 \%)$ were adults, $13(8.55 \%)$ were nymphs and $13(8.55 \%)$ were larvae. Of all the collected ticks, $99.35 \%$ were identified as Ixodes ricinus and Ixodes spp. Of 126 adults, 125 $(82.2 \%)$ were identified as Ixodes ricinus ( + ) and 
$1(0.65 \%)$ was identified as Rhipicephalus sanguineus ( $\left.\sigma^{\lambda}\right)$. All of the 13 nymphs $(8.55 \%)$ and 13 larvae $(8.55 \%)$ were found as Ixodes spp (Table 1). All the adult ticks that are identified as Ixodes ricinus were female (Figure 1). Throughout the study period, $95.24 \%$ of the samples including larvae and nymphs were collected in September. All forms of development cycle were detected in the samples and the forms were inconsistent with the expected cycles. These ticks were examined directly by dark-field microscope and cultured in the Borellia Barbour-Stoenner-Kelly medium. Borrelia spp. were detected by dark field microscope in $3(2.05 \%)$ of the 146 Ixodes and Borrelia spp were determined in $5(3,4 \%)$ of the cultures.

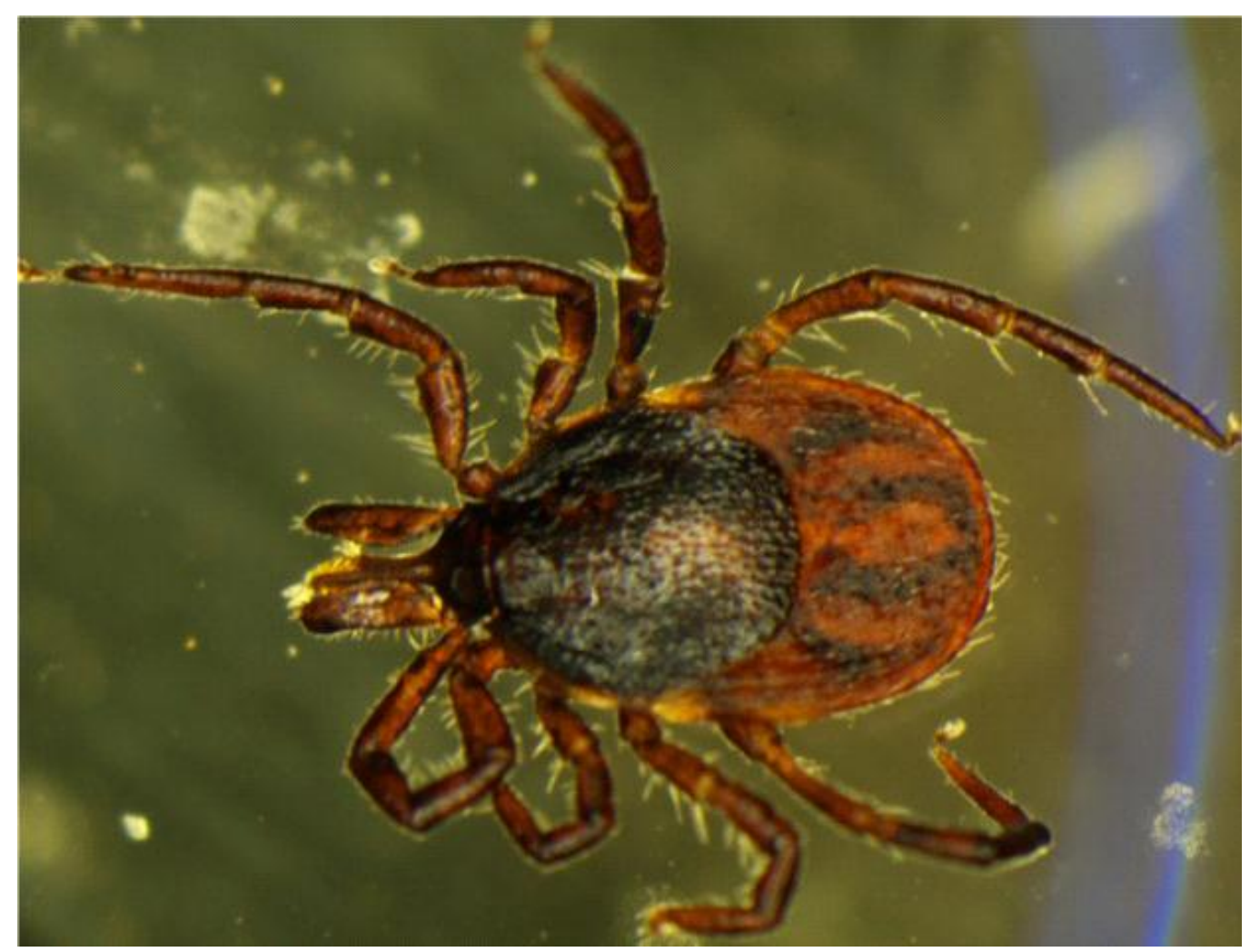

Figure 1. The female Ixodes ricinus

Table 1. The tick species collected from hazelnut farm workers in emergency department

\begin{tabular}{|l|c|c|c|c|c|}
\hline Species & $\begin{array}{c}\text { Male } \\
\mathrm{n}(\%)\end{array}$ & $\begin{array}{c}\text { Female } \\
\mathrm{n}(\%)\end{array}$ & $\begin{array}{c}\text { Larvae } \\
\mathrm{n}(\%)\end{array}$ & $\begin{array}{c}\text { Nymphs } \\
\mathrm{n}(\%)\end{array}$ & TOTAL \\
\hline Ixodes ricinus & - & $\begin{array}{c}125 \\
(\% 82.2)\end{array}$ & - & - & 125 \\
\hline Ixodes spp. & - & - & 13 & 13 \\
$(\% 8.5)$ & - & - & 26 \\
\hline $\begin{array}{l}\text { Rhipicephalus } \\
\text { sanguineus }\end{array}$ & 1 & - & - & 13 & 1 \\
\hline TOTAL & - & $\begin{array}{c}126 \\
(\% 82.8)\end{array}$ & $\begin{array}{c}1 \% 8.5) \\
(\% 8.5)\end{array}$ & 152 \\
\hline
\end{tabular}

All the patients admitted to hospital with tick bite complaint were agricultural workers collecting nuts in our city center or sea-level county (Table 2). 
Table 2. Distribution of farm workers with tick bites by hazelnut agricultural land

\begin{tabular}{|l|c|c|}
\hline Agricultural Lands & (n) & $\%$ \\
\hline Giresun City Center & 23 & 17.1 \\
\hline Bulancak & 22 & 16.4 \\
\hline Kesap & 27 & 20.1 \\
\hline Espiye & 11 & 8.2 \\
\hline Eynesil & 14 & 10.4 \\
\hline Gorele & 14 & 10.4 \\
\hline Piraziz & 13 & 9.7 \\
\hline Tirebolu & 10 & 7.4 \\
\hline TOTAL & 134 & 100 \\
\hline
\end{tabular}

\section{DISCUSSION}

Lyme disease is the most common vector borne infection in the United States. It mostly effects the northeast region and the number of cases is increasing every year. The incidence of the disease in Europe is higher in the northern and central regions ${ }^{14}$. The first case in Turkey was isolated from the Black Sea region ${ }^{15}$. In some areas, the disease was also detected in wild and domestic animals. Despite the presence of seroprevalence studies in various animals and narrow-scoped human case reports, comprehensive epidemiological studies are not available in Turkey ${ }^{9}, 16,17$.

Ixodes spp. are the most important vectors that play role in the spread of Lyme disease. The most known vectors are Ixodes pacificus in the Western Pacific part of North America, Ixodes scapularis in the northeast and midwest of North America, Ixodes ricinus, also known as the sheep tick, in Europe and Ixodes persulcatus in Asia [18]. In our study, 125 (82.23\%) of the identified adults were Ixodes ricinus. All of the 13 nymphs $(8.55 \%)$ and 13 larvae $(8.55 \%)$ were identified as Ixodes spp. (Table 1).

Researchers 19, 20, 21 demonstrated that Ixodes spp. are generally found more intensely in moist and temperate regions. Aydin et al. ${ }^{20}$ reported that Ixodes ricinus is found in a small number in the domestic animals of western Black Sea Region. They also stated that it has never been observed in
Corum, Tokat and Bayburt that are the cities located upcountry and do not have temperate climate of the Black Sea. In the same study ${ }^{20}$, the highest Ixodes ricinus detection rate was in Giresun among seven cities included in the study. All of the ticks $(99.35 \%)$ except one sample were identified as Ixodes spp. in our study and this finding is consistent with the outcomes of the above mentioned study. Moreover all the patients in our study were nut farmers working in the city center or sea-level county which have temperate climate (Table 2).

In the two previous studies that Güner et al. presented ${ }^{22,23}$, it was reported that spirochetes of the genus Borrelia were detected in the $95.8 \%$ and $38.7 \%$ of the Ixodes ricinus ticks collected via flag method from the timberland in Trakya and Sinop, respectively. In addition, Lyme seropositivity rate was detected to be 6 to $35.9 \%$ among agricultural workers ${ }^{24}$. In our work, Borrelia spp. were detected by dark field microscope in $3(2.05 \%)$ of the 146 Ixodes spp. and Borrelia spp were determined in 5 (3.42\%) of the cultures. These results demonstrate that Lyme disease can be seen in our region and the most probable vector is Ixodes ricinus.

All adults that were identified as Ixodes ricinus in our study were female. This can be explained by the fact that the adults complete mating before holding on to the host.

Ixodes ricinus is a three-host tick and can infest all wild and domestic mammals, reptiles and 
humans ${ }^{12}$. The unique features of Black Sea climate such as high rainfall, moisture and vegetation structure allow the presence of this tick intensely in this region. ${ }^{20,21}$. It was reported that the activity of the ticks increase as from November, reach the most intense activity in April and May and decrease excessively between July and October in the Black Sea coast of İstanbul ${ }^{20}$. In the Mediterranean region, Estrada Pena et al. ${ }^{12}$ demonstrated that the adult ticks are active from October until the middle of March while the larva and nymph forms generally show activity between April and July. Selcuk et al. ${ }^{25}$ could not determine any case in Bursa in June-August and reported the least common period that these ticks are seen to be September. They detected the active larvae and nymphs between March and July. On the other hand, inconsistent with these studies, Kar et al. ${ }^{26}$ reported that all forms of Ixodes ricinus are active throughout the year in the Black Sea coast of Istanbul.

Although our study was performed in AugustSeptember, three different development forms of Ixodes ricinus were collected from the patients. The vast majority (95.24\%) of the samples, including larvae and nymphs were collected in September. Dominance of the adult ticks (82.23\%) suggests the high level of activity in these month. Current findings were considered to be in parallel with the results of Kar et al ${ }^{26}$. This fact is considered to arise from the generation of Ixodes ricinus twice or more in a year due to our province's climate features. Aydin and Bakırc1 ${ }^{21}$ also reported that the possible increase in temperature and rainfall can increase the tick population dramatically resulting in spread of the Lyme diseases

\section{CONCLUSIONS}

Consequently, our work is a preliminary study that has been made for the first time in our region. Since the region is narrow and nut harvest season is quite short, the number of samples is limited. However, identification of $99.35 \%$ of the ticks as Ixodes ricinus and Ixodes spp. and determination of all development forms together and inconsistently with the expected development cycle are important findings. The high ratio (17\%) of the larvae and nymphs which are expected to be rarely present in the hosts during the study period and the high overall Lyme carriage rate $(3.42 \%)$ in the ticks are also worth reporting. Additionally misdiagnosis of Lyme is conceivably when the local community and the physicians are not informed properly about the tick-borne diseases. In our region, more comprehensive and organized surveillance studies are planned by screening domestic animal hosts along with the tick bite cases in order to determine vectorial features of the ticks.

\section{Acknowledgement}

This study was presented as poster presentation in 3. National Microbiology Congress (18-22 November, 2015)

\section{REFERENCES}

1. Bakırcı S, Aysul N, Eren H, Ünlü AH, Karagenç T. Diversity of ticks biting humans in Aydın province of Turkey. Ankara Üniv Vet Fak Derg 2014; 61: 93-8.

2. Hekimoğlu O, Özer AN. Distribution of hard tick species in Ankara, Turkey. Turk J Zool 2015; 39: 256-62.

3. İça A, Özkan F. Kütahya Yöresi'nde Yayılış Gösteren Kene Türlerinin Araştırılması. Turkiye Parazitol Derg 2015;39: 117-23.

4. Aydın MF. A Preliminary Study for Determining Tick Species Attached Humans in Bitlis Province of Turkey. F Ü Sağ Bil Vet Derg 2015; 29: 19-21.

5. Şen E. Küresel ısınmanın kenelerle taşınan enfeksiyonlara etkileri. Turk Mikrobiyol Cem Derg 2007; 37: 176-88.

6. Arıkan D, Tıraş Ü, Saraçoğlu D, Tasar MA, Dallar Y. Kene 1sırığı nedeniyle basvuran olguların değerlendirilmesi. Ege Tip Dergisi 2009; 48: 2931.

7. Jongejan F, Uilenberg G. The global importance of ticks. Parasitology 2004; 129: 3-14.

8. Sarı B, Taşkın G, Kılıç Y. Seroprevalence of Dirofilaria immitis, Ehrlichia canis and Borrelia burgdorferi in Dogs in Iğdır Province, Turkey. Kafkas Univ Vet Fak Derg. 2013; 19: 735-39.

9. Bulut C, Zeliha Kocak Tufan Z, Altun Ş, Altınel E, Kınıklı S, Demiroz AP. Kene 1sırıklarında gözden kaçan bir hastalı: Lyme hastalığı. Mikrobiyol Bul 2009; 43: 487-92.

10. Steere AC. Lyme disease. New Engl J Med 2001; 345: 115-25.

11. Merdivenci A. Türkiye keneleri üzerine araştırmalar. In, Merdivenci A. (Ed): 1. Bask1, Kutulmuş Matbaası, İstanbul, 1969.

12. Estrada-Peña A, Bouattour A, Camicas JL, Walker AR. Ticks of Domestic Animals in the Mediterrean Region: A Guide to Identification of Species. 2nd Ed, Bioscience Reports, Scotland, 2004. 
13. Karaer Z, Yukarı BA, Aydın L. Türkiye Keneleri ve Vektörlükleri. Editörler. Özcel MA, Daldal N: Artropod Hastalıkları Vektörler. Türkiye Parazitoloji Derneği Yayınları 1997; 13: 363-434.

14. Yemişen $M$, Mete $B$, Balkan III. Lyme hastalığı. Deneysel ve Klinik Tip Dergisi 2012; 29: 169-74.

15. Polat E, Çalışır B, Yücel A, Tüzer E. Türkiye'de Ixodes ricinus'lardan ilk defa ayrılan ve üretilen iki Borrelia Kökeni. T Parasitol Derg 1998; 22: 16673.

16. Türkiye Halk Sağlığı Kurumu. Ulusal mikrobiyoloji standartları: Lyme Hastalığının Mikrobiyolojik Tanısı. 2015. Available at:http://mikrobiyoloji.thsk.saglik.gov.tr.

Retrieved January 1, 2015.

17. Polat E, Turhan V, Aslan M, Müsellim B, Önem Y, Ertuğrul B. Türkiye'de ilk kez etkenleri kultürde üretilen üç insan Lyme Hastalı̆̆g olgusu. Mikrobiyol Bul 2010; 44: 133-39.

18. Gray JS. The ecology of ticks transmitting Lyme borreliosis. Exp Appl Acarol 1998; 22: 24958 ,

19. Bursali A, Keskin A, Tekin S. A review of the ticks (Acari: Ixodida) of Turkey: species diversity, hosts and geographical distribution. Exp Appl Acarol 2012; 57: 91-104.

20. Aydın MF, Aktaş M, Dumanlı N. Türkiye'nin Karadeniz Bölgesindeki Koyun ve Keçilerde Kene
Enfestasyonları. Kafkas Univ Vet Fak Derg 2010; 18: 17-22.

21. Aydın L, Bakırcı S. Geographical distribution of ticks in Turkey. Parasitol Res 2007; $101: 163$ 66.

22. Güner, ES, Hashimoto N, Takada N, Kaneda K, Imai Y, Masuzawa T. First isolation and characterization of Borrelia burgdorferi sensu lato strains from Ixodes ricinus ticks in Turkey. J Med Microbiol 2003; 52, 807-13.

23. Güner ES, Watanabe M, Kadosaka T, Polat E, Gargili A, Gulanber A, Ohashi N, Kaneda K, Imai Y, Masuzawa T. Seroepide- miology of Borrelia burgdorferi sensulato and Anaplasma phagocytophilum in wild mice captured in northern Turkey. Epidemiol Infect 2005; 133: 331-36.

24. Yemisen M, Mete $B$, Balkan İ. Lyme Hastalığ 1 . Journal of Experimental and Clinical Medicine 2012; 29: 169-74.

25. Selçuk Ö, Alver Ö, Çatık S, Aydın L, Şenlik B. Determination of Diagnostic Value of ELISA for the Diagnosis of Anaplasmosis in Clinically Suspected Ruminants. Kafkas Univ Vet Fak Derg 2015; 21: 691-5.

26. Kar S, Y1lmazer N, Midilli K, Ergin S, Gargilı A. Borrelia burgdorferi s.l. and Rickettsia spp. in Ticks Collected from European Part of Turkey. Kafkas Univ Vet Fak Derg 2013; 19: 19-24. 